\title{
Description of the pelargonium butterfly Cacyreus marshalli Butler (Lepidoptera: Lycaenidae: Polyommatinae)
}

\author{
Mohamed E. Tawfeek ${ }^{1}$, Mohamed A. Abu Ghonem ${ }^{2}$, Hanan M. Ramadan ${ }^{1}$ and Amany M. Abu-Shall
}

\begin{abstract}
The geranium bronze butterfly Cacyreus marshalli Butler, 1898, (Lepidoptera: Lycaenidae: Polyommatinae: Polyommatini) is an important pest of some ornamental plants. It infests flowers, neck of flowers and borrows in the stem of Pelargonium zonale and $P$. inquinans (Geraniaceae) in many districts in Alexandria Governorate. Morphology of each stage (egg, larva, pupa and adults [male $\&$ female]) of this butterfly was described in detail. As well as, Scanning Electron Microscopy (SEM) photographs for egg were taken. Larvae are elongate (onisciform) slightly flattened and yellowish to light green in colour. The obtect pupae are with dorsal aspect darker than the ventral one, with abdominal parts pale yellowish in colour and with dense long hairs dorsally. Male is slightly shorter than female. Forewing and hindwing with dorsal side brown in colour and with white and brown fine bands on edges in both sexes. The diagnostic characteirstics of adult male and female were described in detail. Ultrastructure of antennal sensilla were described and photographed by SEM photographe.
\end{abstract}

Keywords: Cacyreus marshalli Butler, 1898, Morphological studies, antennal sensilla, diagnostic characters.

\section{INTRODUCTION}

In recent decades, the lycaenid geranium bronze butterfly Cacyreus marshalli Butler, 1898, has received much attention because of the damage caused to ornamental species of Geranium and Pelargonium. $C$. marschalli Butler is an invasive species in many parts of Europe and Mediterranean area. The caterpillar was recorded for the first time in England 1978 and in Mallorca in 1988 (Heaths et al., 2002). Later on, Eitschberger and Stamer in 1990 recorded it as a new pest in Europe. Also, it was recoded in Majorca (Raynor, 1990), from mainland in Belgium in 1991 and in Spain in 1992 (Sarto and Monteys, 1992). C. marshalli is an invasive species in many parts of Italy 1996 (Trematerra et al., 1997), in Sardinia in 1997, France, Portugal and in Morocco in 1997 (Tarrier, 1998 \& Quacchia et al., 2008). Malta Island (Sammut, 2007), western coast of the Balkan Peninsula (Marko and Verovnik, 2009), in Sicily 2001, in southern

DOI: 10.21608/asejaiqjsae.2021.208864

${ }^{1}$ Faculty of Agriculture, Alexandria University,

Dept. of Applied Entomology and Zoology

${ }^{2}$ Alexandria University Administration gardens and nurseries

Received November 11, 2021, Accepted, December 12, 2021.
Switzerland 2002, in Slovenia 2008 and in Croatia (Tolman and Lewington, 2009; Verovnik et al., 2011; Kissling, 2012; Kučinić et al., 2014). This species was also established in Belgium, Germany, the Netherlands and the United Kingdom but was unable to survive the winter season (Gross, 2010). Also, it was recorded in Turky (Tarkan et al., 2013). It was naturally distributed in many countries from South Africa such as Mozambique, Zambia and Zimbabwe (Heaths et al., 2002). The species was first recorded in Corfu 2008 (Parker, 2010). Also, it was recorded in Attica (Athens and Spétses Island) by Anastassiu et al. (2010), More studies on it were carried out in Greece, by Coutsis et al. (2011) \& Martinou et al. (2011). Gilbert and Zalat (2007), Tshikolovets (2011) and Numa et al. (2015) recorded among the threatenedt species of Medeterranean butterflies. In their Atlas about Butterflies of Egypt did not list C. marshalli.

In 2017, the authos of the present study recorded it as new to the Egyptian fauna (Abu Ghonem et al., 2017). The present study aimed to study the morphology of this butterfly since it is new pest of pelargonium in Egypt.

\section{MATERIALS AND METHODS}

\section{- Insect collection:}

During 2017 several individuals of the pelargonium butterfly Cacyreus marshalli Butler, 1898 (Lepidoptera: Lycaenidae: Polyommatinae: Polyommatini) were observed in Alexandria. They were infesting Pelargonium zonale and $P$. inquinans (Geraniaceae). Adults and immature stages of $C$. marshalli were collected from the arboretum of Faculty of Agriculture, Al-Shatby $(31206319,29919693)$ and Faculty of Fine Art (312377339,2996606), Alexandria University, Police hospital gardens (31193748,29923761), Antoniades garden $(31200861,29952300)$ and ElMontazah palace gardens (31288936,30015980).

\section{- Slide preparation:}

Adults male and female of pelargomiun butterfly were dissected under stereoscopic bionocular microscopae and prepared as whole mounts for light microscopic examination by soaking in $10 \% \mathrm{NaOH}$ 
solution for a week then rinsed in distilled water several times. The specimens were passed through series of ethyl alcohol from 60-95\% then to absolute alcohol, one hour for each concentration. After that they were cleared in clove oil for one hour and then mounted on slides using Canada balsam medium. The slides were dried at $50^{\circ} \mathrm{C}$. For wing description, the terminology of Kunte and Tiple (2009) was used (Figure, 1). The nomenclature and terminology of genitalia is according to Sibatanp et al. (1954). Prepared specimens were examined and photographed under a stereoscopic microscope.

For scanning electron microscopy (SEM) examination, the eggs, mature larvae, pupae and the male and female antennae were dried in a series of ethanol to $96 \%$. They were mounted on copper stub by using double faced adhesive tape. The mounted specimens were prepared for SEM examination at the Faculty of Science, Alexandria University. They were coated with gold in a Joel JEC-1100E for 18 minutes to thickness of $12 \mathrm{~nm}$. Then examined and photographed with a JEOL (JSM-5300) scanning electron microscope.

\section{RESULTS AND DISCUSSION}

\section{- Symptoms of infestation:}

First instar larvae feed on Pelargonium leaves, (Figure, $2 \mathrm{~A}$ ), flowers and neck of flowers, so the latter welt. Second, third and fourth instars borrow in the stem (Figure, $2 \mathrm{~B}$ ) of $P$. zonale making galleries. The bored galleries by larvae filled with excrement (Figure, $2 \mathrm{C}$ ). Flowers can be totally eaten by larvae. The adult feeds on flowers nectar.

\section{-Description of the immature stages:}

Eggs: female of $C$. marshelli lay eggs individually on the upper and lower leaf surfaces, less frequently on stem or on the flower (Figure, $3 \mathrm{~A}, \mathrm{~B} \& \mathrm{C}$ ). The eggs are turban-shaped with flattened base and a depression at the top, which containing the micropyle. It is white in colour initially but turns blackish just before hatching. It is about $0.5 \mathrm{~mm}$ in diameter $\mathrm{x} 0.3 \mathrm{~mm}$ in height. SEM examination of the egg shell showed its architectural pattern (egg decoration) which is depending on the arrangement of ovariol follicular imprints (Figure, $3 \mathrm{D}$ ).

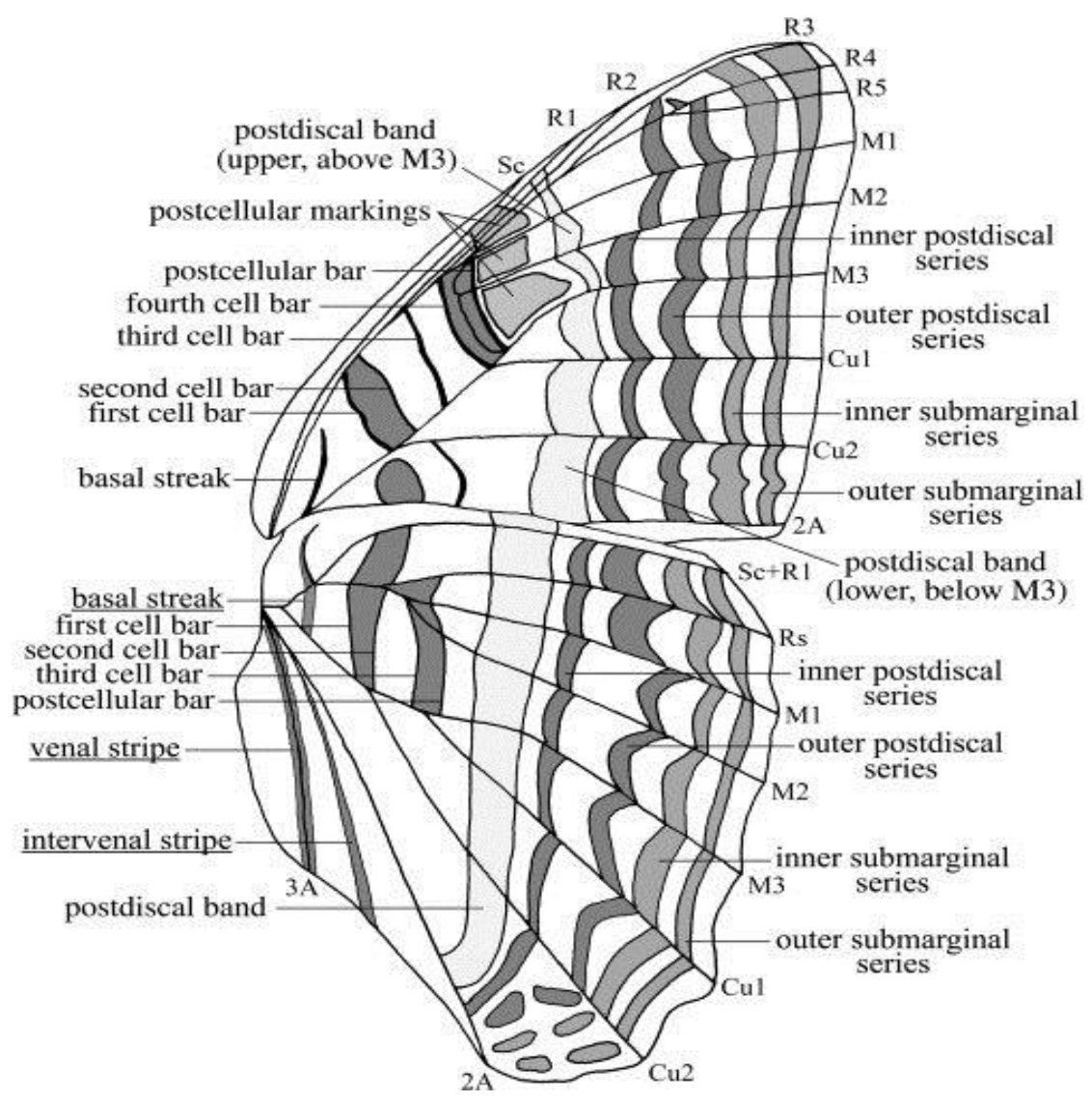

Figure 1. Wing pattern elements of butterflies (after Kunte and Tiple 2009). 


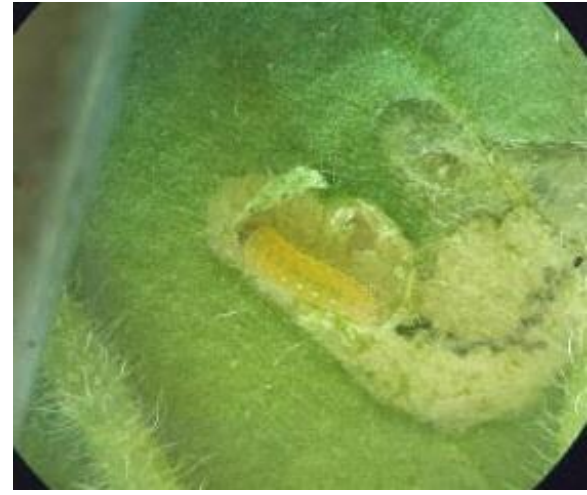

A

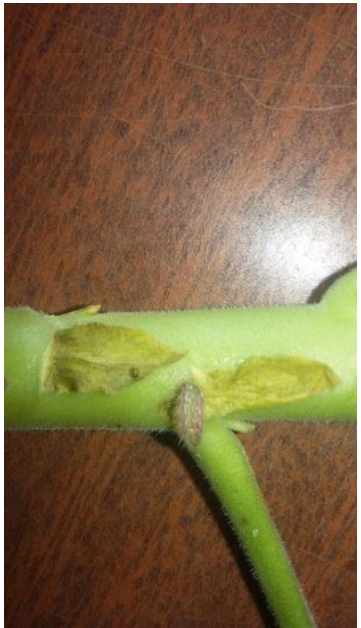

B

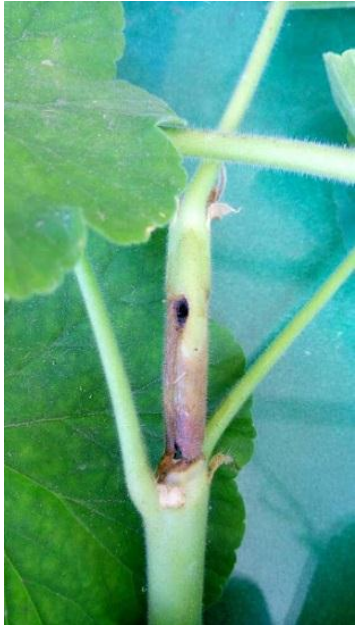

C

Figure 2. Showed symptoms of infestation of Pelargonium plants by Cacyreus marshalli larvae (A: leaves, B: stem of plant, C: flower bud).

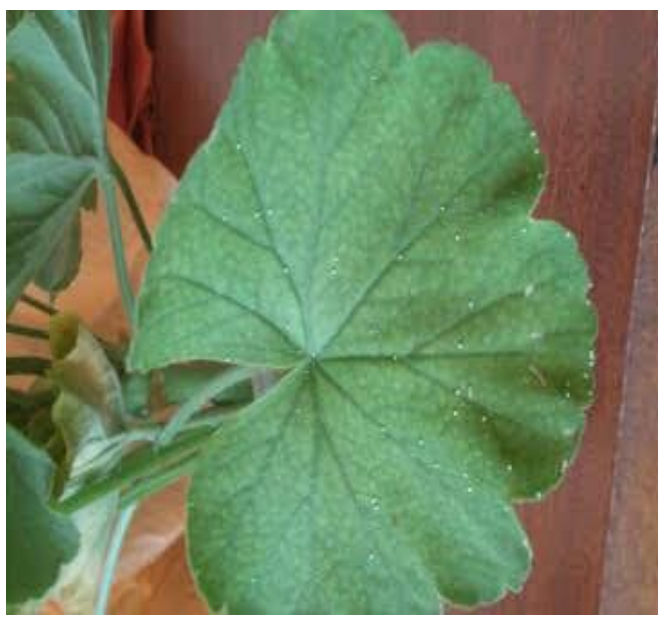

$\mathbf{A}$

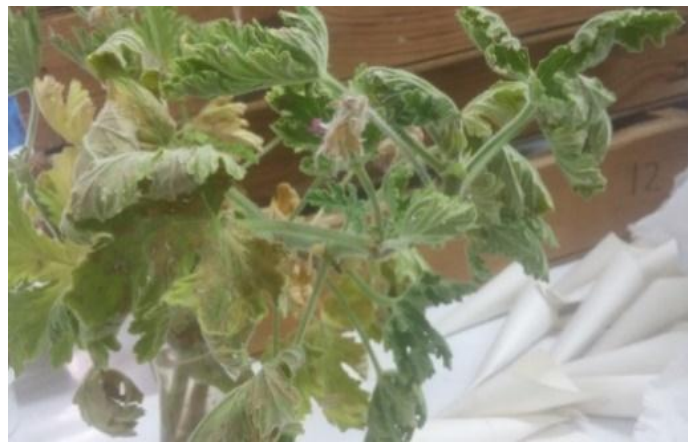

C

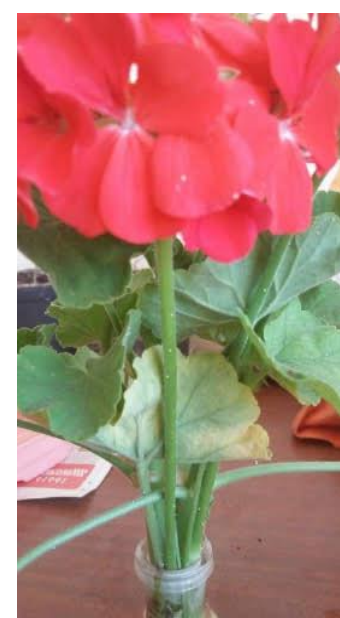

B

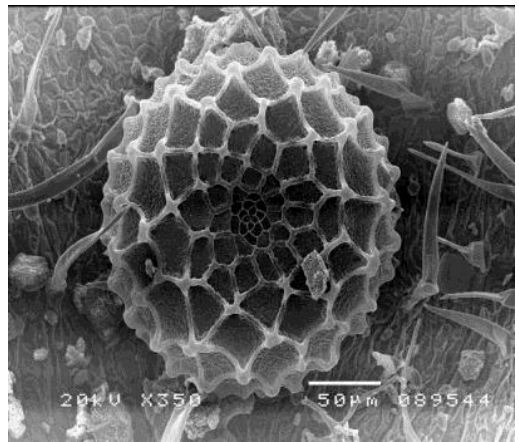

D

Figure 3. Photographs of Cacyreus marshalli eggs on (A) lower surface of pelargonium leaves and (B) flower petals on (C) leaves of geranium and (D) SEM photograph general appearance. 
Lavae: the larvae are elongate (onisciform) slightly flattened. First instar is yellowish in colour; instars from 2 to 4 are light green in colour with reddish irregular longitudinal lines extending along the body length. Last instar larva with small, dark brown, shining head capsule concealed in the thoracic segments. They have two distinct colours, either bright green or dark reddish purple. First instar larva are about $1.3 \mathrm{~mm}$. in length, second instar is slightly darker, about $2.8 \mathrm{~mm}$. in length, the third instar about $6 \mathrm{~mm}$., while the last instar is about $13.1 \mathrm{~mm}$. in length (Figure, $4 \mathrm{~B}$ ).

Pupae: Pupation takes place between the peduncles of leaves and the stem. The obtect pupae (Figure, 5 A \& B) are with dorsal aspect darker than ventral one and with abdominal parts pale yellowish in colour. The dorsal surface provided with dense long hairs.

Adult stage: Male is about $10-13 \mathrm{~mm}$. $(12 \mathrm{~mm}$. in average) in length. The wing span is about $15-23 \mathrm{~mm}$. (19 $\mathrm{mm}$. in average). Female slightly longer averaged $13 \mathrm{~mm}$. in length and wing span from $18-27 \mathrm{~mm}$. (23 $\mathrm{mm}$. average). Forewing and hindwing from dorsal side brown in colour with white and brown fine bands on edges in both sexes (Figure, 6).

Head: Compound eyes are large and composed of many facets (Figure, 7 A \& B, Om.). Simple eyes are absent. Antenna clavate (Figure, 8 A \& B) consists of 34 segments in both sexes. Antennae segments of flagellum with dense overlapping, leaf like irregular arrangement of pointed cuticular plates or scales known as microtrachia (Figure, 8 D \& F, Mt.). There are different types of sensilla on ventral side of club which provided with dense delicate trichoid sensilla (Figure, $8 \mathrm{C}$, st.) and few sensillae chaetica (Figure, $8 \mathrm{C} \& \mathrm{D}$, Sch.). Böhm's bristles (Figure, $8 \mathrm{E}, \mathrm{Bb}$.) are present in tubercles at the basal region of the scape and the intersegmental region between the scape and pedicel. Also, sensilla squamiform are found near this tubercle (Figure, $8 \mathrm{E}$, Sq.). Many scales surrounded the antennal base (Figure, 8 E \& F, S.).

Thorax: the prothorax is the smallest of the three thoracic segments, with a pair of spiracles. Female legs are similar in shape and size with five segmented tarsus with a piar of large curved claws and longer finger like pullvillus (Figure, 9 A \& B) while the fore leg in male is reduced with only one segmented tarsus terminating with a ventrally curved spinose claw and very short finger pulvillus (Figure, $9 \mathrm{C}$ ).

Female wings: Upper side (Figure, $10 \mathrm{~A}$ ) of fore wing is brown or bronze in darker colour in the base of wing with dark brown viens. Costal margin with fine dark brown incomplete line and white spots nearer to the outer margin. There are white and brown mutualy spots on the outer margin with irregular length of cilia, while the anal margin with brown short cilia. Hind wing similar to front wing but slightly broader. The submarginal area with a band white spots on the fringe at the upper side and with rounded black spot just above the filamentous tail.

The underside of fore wing is light brown in colour with brown markings. There is a median brown rectangular band between first and second cells which are surrounded by white slightly broad irregular white lines. Also, postcellular bar broad brown band surrounded by white lines. Inner and outer post discal series white including broad brown band. The inner and outer submarginal area are represented by brown obscured broad line. Termine is dark brown thin line flowed by brown and white cilia.

Hind wing underside with light brown humeral angle and with brown broad rectangular band between first and second cell white bar. Postcellular bar brown surrounded by white line. Inner postdiscal series consists of two bands one brown triangular near the costal margin and the other rectangular irregular brown band surrounding by dark brown irregular thin line posteriorly, followed by $\mathrm{M}$ shaped white spot near anal margin. Inner submarginal series whitish in colour near costal margin and smoky in coolr near anal margin. Thin dark brown line found in the outer margin followed by irregular light brown cilia. There is black rounded spot just above the flimentous tail

Male wing: male forewing and hindwing are similar to female from upper side (Figure, $10 \mathrm{~B}$ ) but the fine dark brown incomplete line and white spots nearer to the outer margin are more clear than female.

Abdomen: it coprises of 10 segments, the first seven having spiracles. The last two or three segments are greatly modified to form the external genitalia. There is a dense tuft of long hairs (pencil hairs) at the end of male abdomen associated to scent gland and used for the courtship (Figure, 11).

Male genitalia: (Figure, 12) is apendges of eighth and ninth abdominal segments. The ninth segment is a sclerotized well-developed dorsal tegumen (teg.). Valvea (Val.) are broad baselly sclerotized plates, apex rounded, with pointed transverse spine valval lobe midially (Vb). Sacculus (Sac.) is sclerotized, gradually thinner process found midventrally forwards from the vinculum, juxta small while uncus is a pair curved down middorsal attached posteriorly to the tegumen. Clasper (Cl) well-developed, with strong pointed apical process stout, falcate-like protruded below vinculum (Vn). Gnathos is a pair of long separate hooks known as brachia attached also posteriorly to the tegumen. 


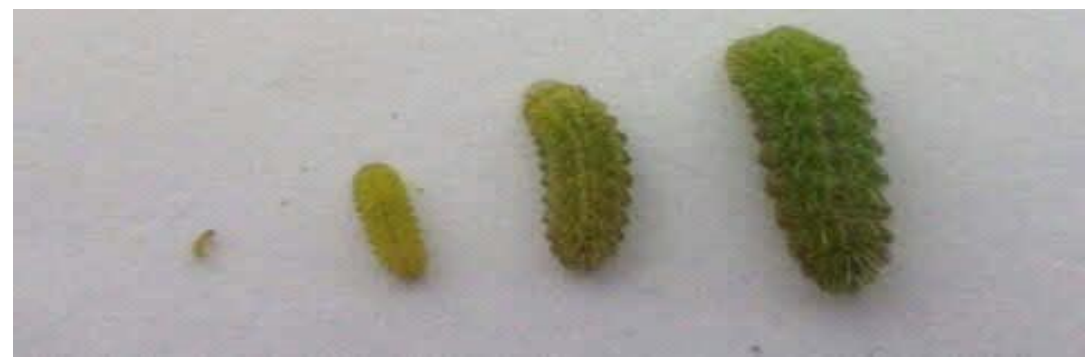

Figure 4. The four larval instars of Cacyreus marshalli.
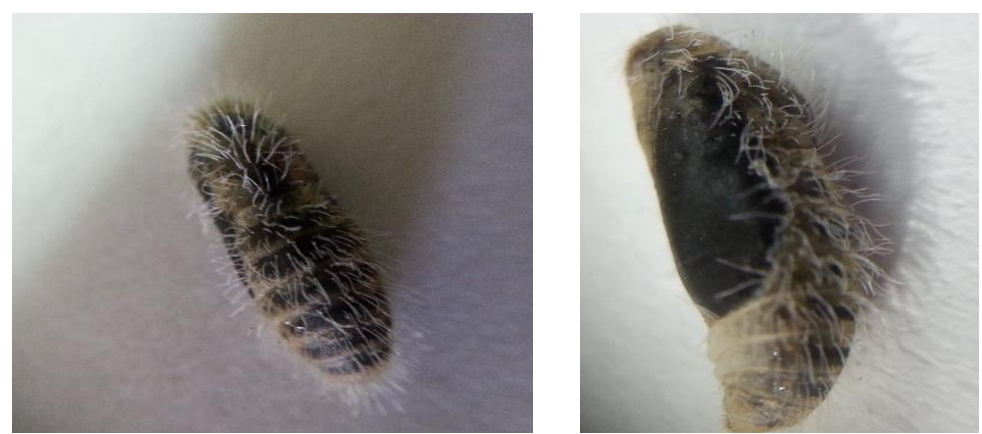

Figure 5. Dorsal and lateral view of Cacyreus marshalli obtect pupae.

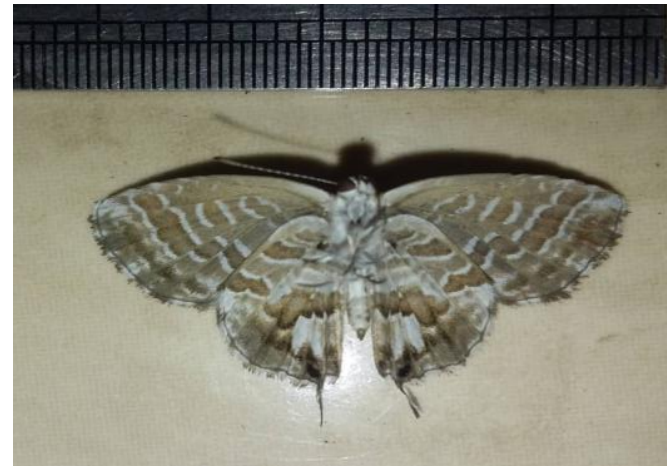

$\mathbf{A}$

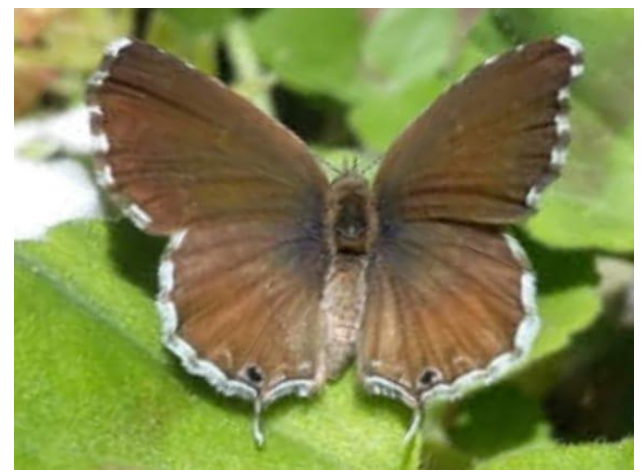

B

Figure 6. Dorsal and ventral views of Cacyreus marshalli adult (A: Female, B: Male).

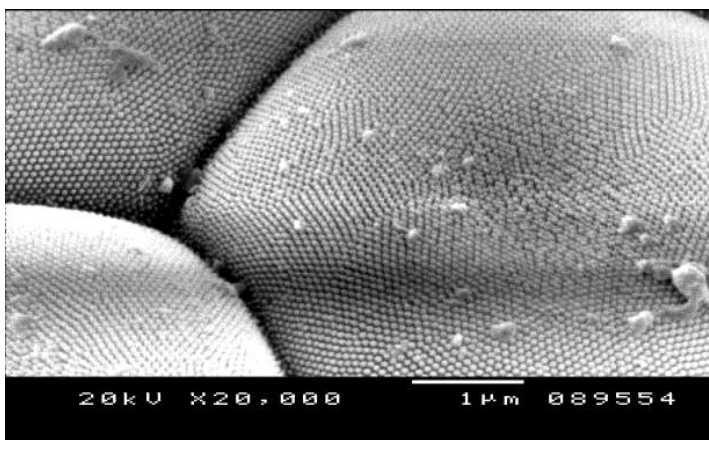

A

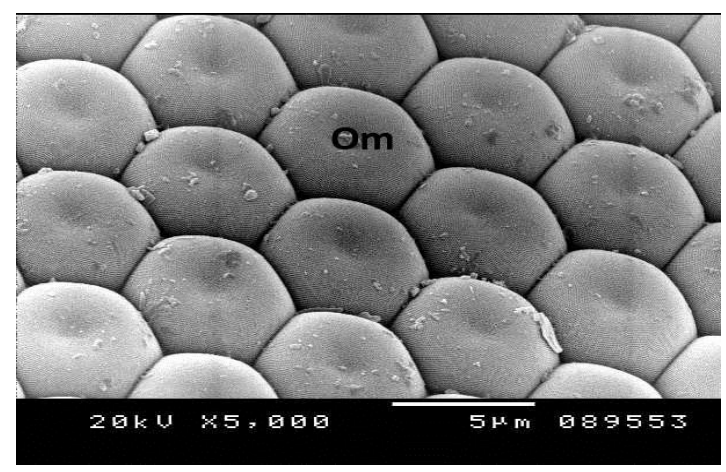

B

Figure 7. (A) Compound eye of Cacyreus marshalli adult, (B) Magnification of facets or ommatidium (Om.). 


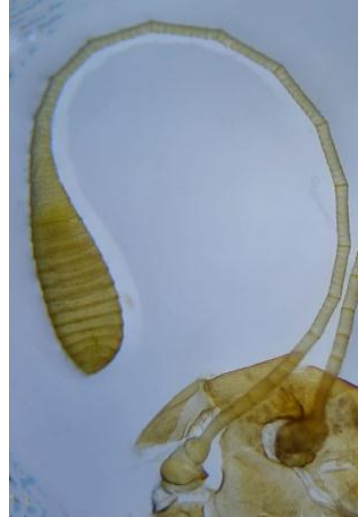

$\mathbf{A}$

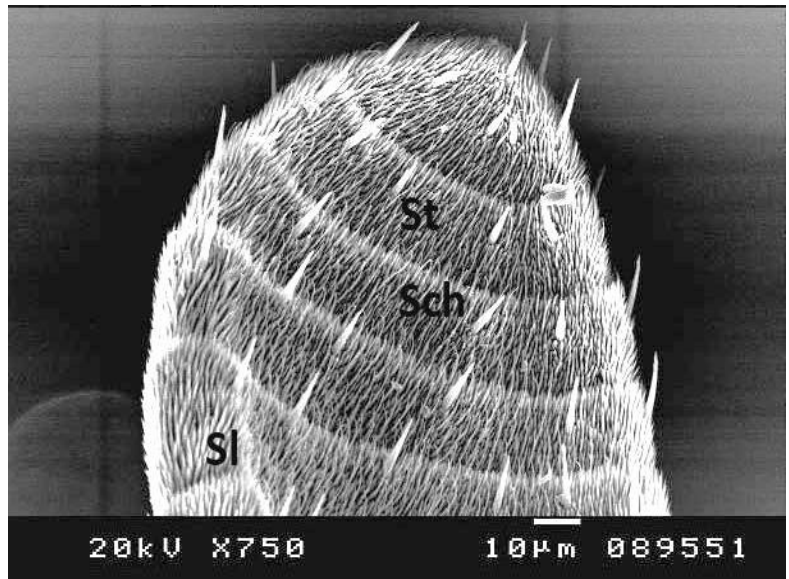

C

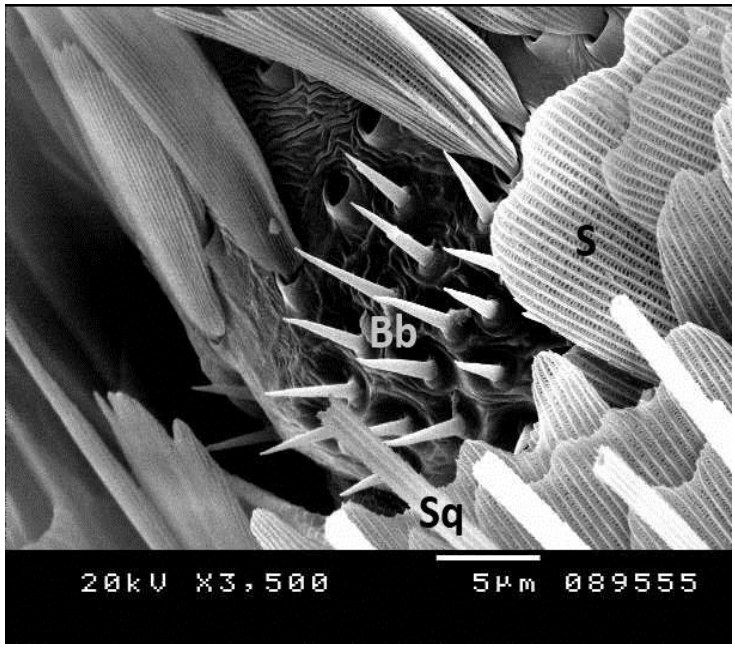

$\mathbf{E}$

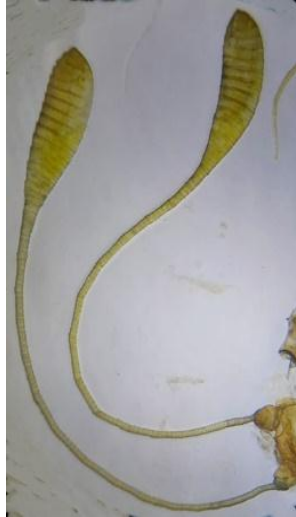

B

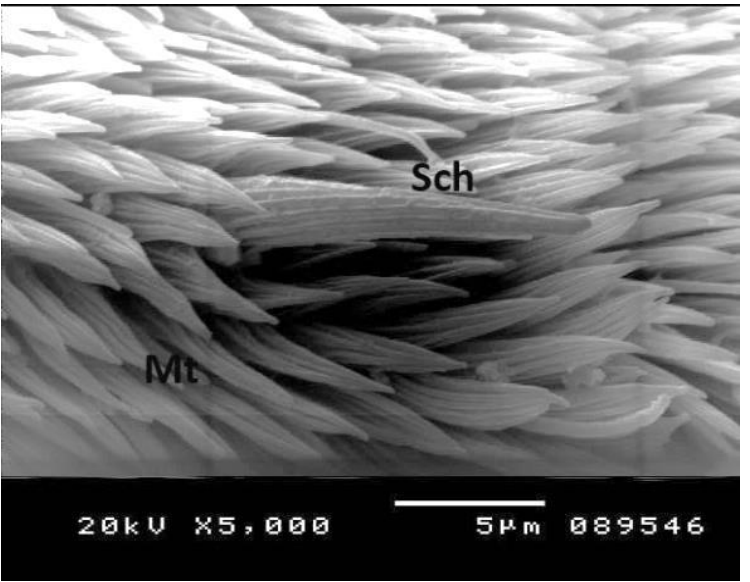

$\mathbf{D}$

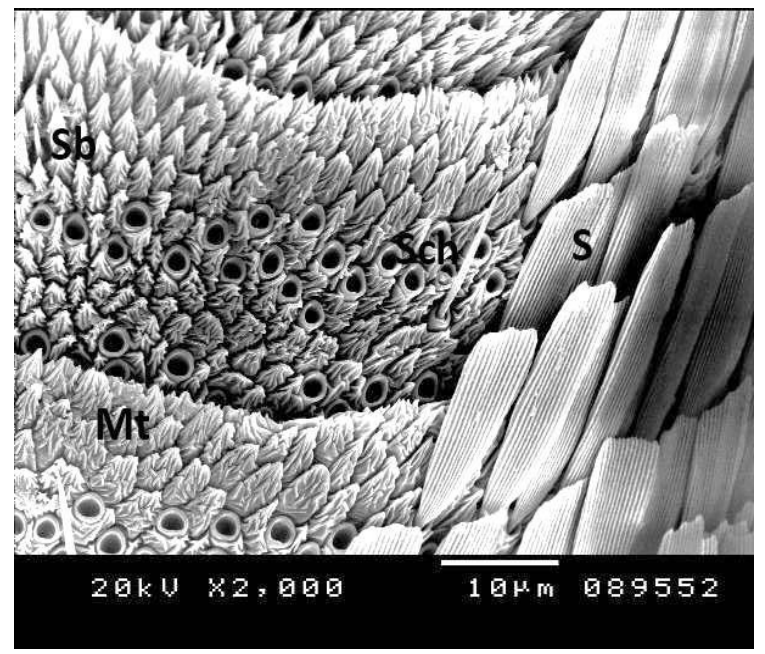

$\mathbf{F}$

Figure 8. Microphotograph of Cacyreus marshalli showing (A) Female antennae, (B) Male antennae, (C) SEM photograph of antennal club, (D) dense overlapping trichoid sensillae and styliconic sensilla, (E) scales covered antennae, (F) antennal base (Bb., Bohom's bristle; Mt., Microtrachia; S., Scales, Sch., Sensilla chaetica; Sq., Sensella squamiformia; St., trichoid sensilla). 


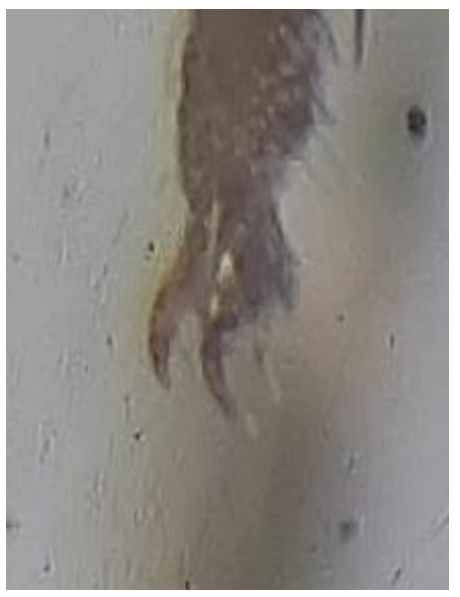

A

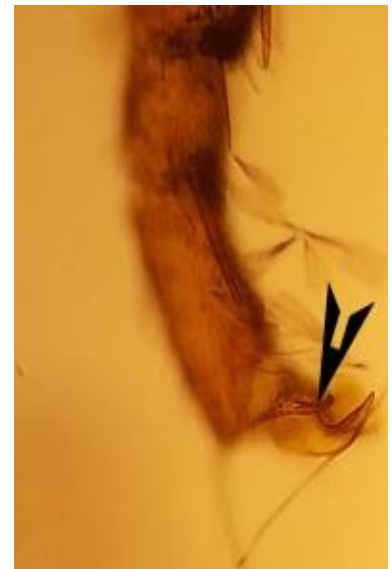

B

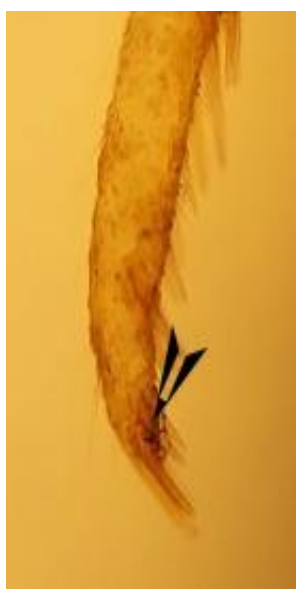

C

Figure 9. End of fore leg (A) Female, (B) tarsal claw of Female fore leg, (C) end of fore leg Male. Arrows indicated the finger like pulvillus.

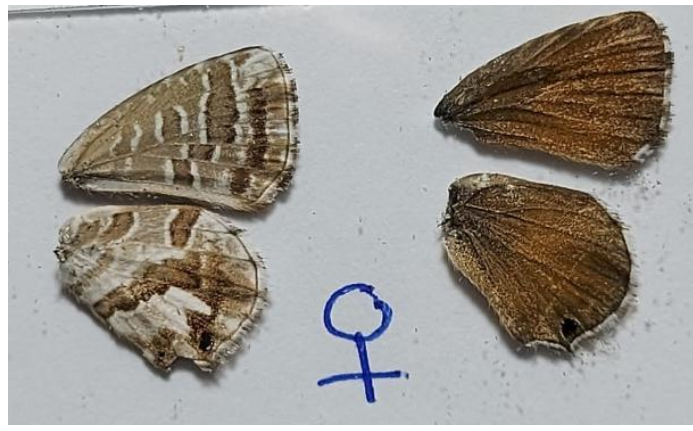

A

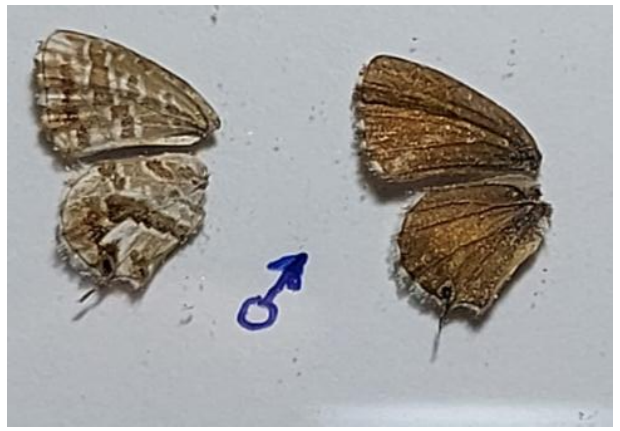

B

Figure 10. Upper and lower sides of Cacyreus marshalli (A: Female, B: Male).

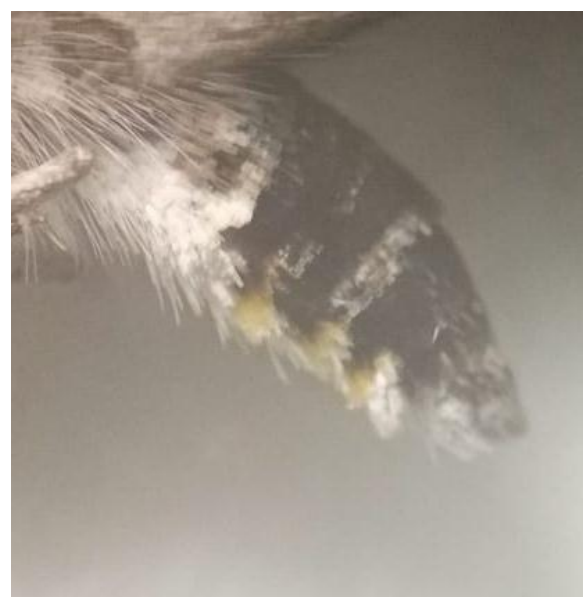

A

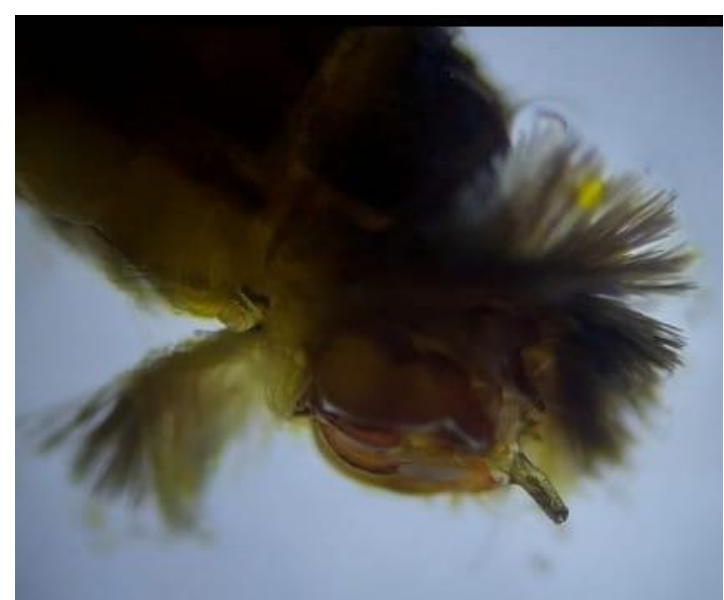

B

Figure 11. Cacyreus marshalli (A) end of Male abdomen and (B) hair pencil of Male. 


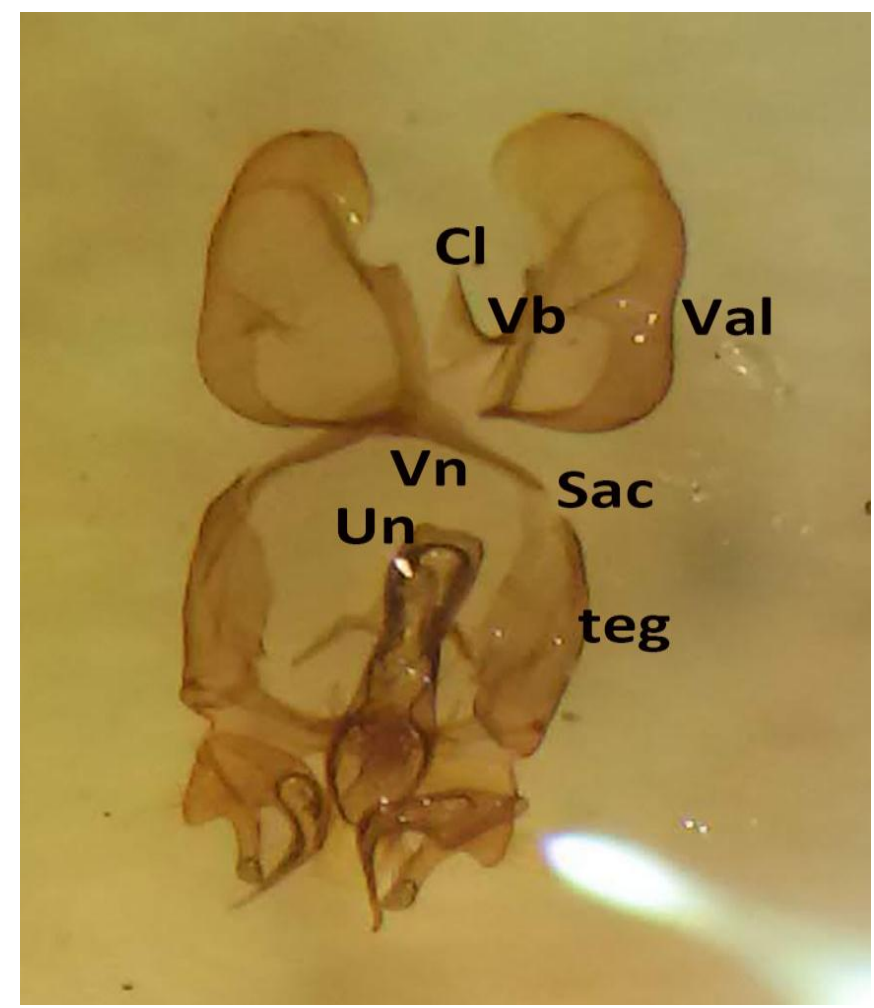

Figure 12. Photograph of Cacyreus marshalli male genetalia (Cl., Clasper; Sac, Sacculus; teg., Tegument; Un., Uncus; Val., Valva; Vb., Valval lobe; Vn., Vinaculium).

Female genital: female of $C$. marshalli as in most lepidopterous adult females have two genital openings, one at the posterior end of the abdomen, used for egg laying, and the other, on the midventral line between the $7^{\text {th }}$ anf $8^{\text {th }}$ sternites, is used for mating. Segments 8,9 and 10 form a retractile ovipositor. A pair of hairy pads, the papillae anals, are found at the end of a pair of internal rod-like apophysis. The copulatory opening is bordered by sclerotized plats and leading to the duct bursa, the latter leading to the membranous sac (corpus bursae) in which the spermatophors were put. The internal surface of the corpus bursae with two thickend plates, known as signa (Figure, 13).

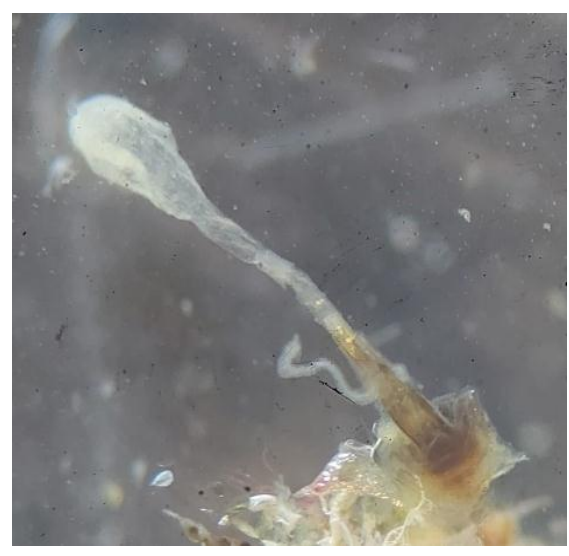

A

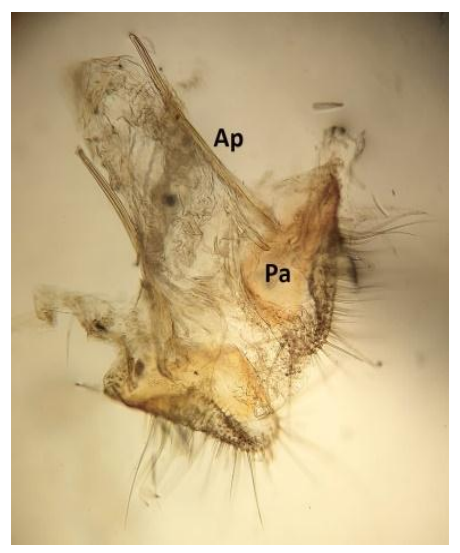

B

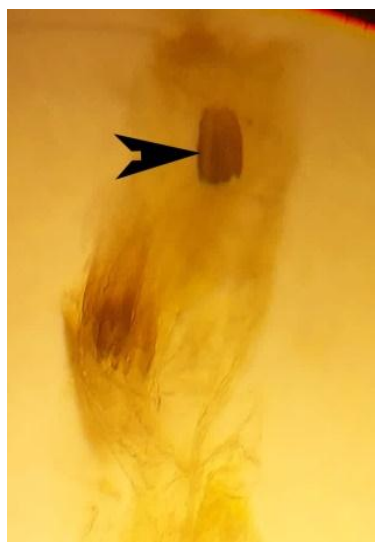

C

Figure 13. Bursa copulatrix of Cacyreus marshalli female bursa capulatrex (A) female genitalia, (B) magnified portion of papilla (Pa) and apophysis (Ap), (C) magnified portion bursa copulatix sac arrow showed signa. 


\section{REFERENCES}

Abu Ghonem, M.A., H.M. Ramadan, A. M. Abu-Shall and M. E. Tawfeek. 2017. Scientific Note First recorded of the pelargonium butterfly Cacyreus marshalli Butler, 1898 (Lepidoptera: Lycaenidae: Polyommatinae: Polyommatini) in Alexandria, Egypt. Alex. J. Agric. Sci. 62(2), $219-222$.

Anastassiu, H. T., N. Ghavalas and J. G. Coutsis. 2010. First record of Cacyreus marshalli in Greece and comments on the potential occurrence of Zizeeria karsandra on the Greek island of Crete (Lepidoptera: Lycaenidae). Phegea. 38 (3), 85-92.

Coutsis, J. G., H. T. Anastassiu and N. Ghavalas. 2011. An explanatory note on a previous article of ours, Population fluctuations of the imported Cacyreus marshalli in Greece, and an assessment of its being a potential threat through larval competition to native butterflies with Geranium feeding larvae (Lepidoptera: Lycaenidae). Phegea. 39 (2), 43-44.

Eitschberger, U and P. Stamer. 1990. Cacyrreus marshalli Butler, 1898, eine neue Tagfalterat fur die europaische Founa? (Lepidoptera: Lycaenidae). Atalanta 21(1/2), 101108.

Gilbert, F and S. Zalat. 2007. Butterflies of Egypt Atlas, Red Data listing and Conservation. Arab Republic of Egypt. Ministry of State for Environmental Affairs Agency. Nature Conservation Sector. pp. 196.

Gross, P. 2010. Achtung: Neozoen im Anmarsch! Der Pelargonien-Bläuling (Cacyreus marshalli Butler, 1898) in Europa.Ein Beispiel für die ausnahmsweise gut dokumentierte Expansion eines Neozoons underste Meldung dieser Tagfalterart aus Istrien (Kroatein) Salzburger Entomologische Arbeitsgemeinschaft Haus der Natur Newsletter. 2, 8-11.

Heaths, A., M. A. Newport and D. Hanncock. 2002. The Butterflies of Zambia. American Butterfly Research Institute and the Lepidopterests Society of Africa. pp. 137.

Kucinic, M., M. Randic, I. Mihoci, T. Koren, A. Mrnjavcic, B. Laus Vojvoda and I. Buric. 2014. Contribution to knowledge of the distribution of the Geranium Bronze Cacyreus marshalli (Butler, 1898) (Lepidoptera: Lycaenidae) in Croatia with note on ecology and ethology. Entomol. Croat. 18 (1-2), 49-57.

Kissling, $\quad$ T. 2012. Cacyreus marshalli. http://www.lepiforum.de/cgibin/2_forum.pl?md=read;id=84671.

Kunte, K and A. Tiple. 2009. The polyommatine wing pattern elements and seasonal polyphenism of the Indian Chilades pandava butterfly (Lepidoptera: Lycaenidae). News Lepidopterists Soc. 51, 86-109.

Marko, K and R. Verovnik. 2009. First record of Cacyreus marshalli (Lycaenidae) from the Balkan Peninsula. Nota lepidoptero logica. 32 (1), 81-82.
Martinou, A. F., D. Papachristos and P. G. Mi- lonas. 2011. Report of the Geranium Bronze Butterfly, Cacyreus marshalli for mainland Greece. Hellenic Plant Protec-tion Journal. 4, 31-34.

Numa, C., C. van Swaay, I. Wynhoff, M. Wiemers, V. Barrios, D. Allen, C. Sayer, M. L. Munguira, E. Balletto, D. Ben- yamini, S. Beshkov, S. Bonelli, R. Caruana, L. Dapporto, F. Franeta, P. Garcia- Pereira, E. Karaçetin, A. Katbeh-Bader, D. Maes, N. Micevski, R. Miller, E. Monteiro, R. Moulai, A. Nieto, L. Pamperis, G. Pe'er, A. Power, M. Šašic', K. Thompson, E. Tzirkalli, R. Verovnik, M. Warren and H. Welch. 2015. The status and distribution of Mediterranean butterflies. The IUCN Red List of Threatened Species TM - Regional Assessment. pp 46.

Parker, R. 2010. Cacyreus marshalli Butler, 1898 (Lepidoptera: Lycaenidae) newly recorded for Corfu, with notes on other butterflies on the island in September 2008. Entomologist's Gazette. 61, 40-42.

Quacchia, A., C. Ferracini, S. Bonelli, E. Balletto and A. Alma. 2008. Can the Geranium Bronze, Cacyreus marshalli, become a threat for European biodiversity? Biodiver- sity and Conservation. 17, 1429-1437.

Raynor, E. M. 1990. The occurrence of a Cacyreus species (Lep.: Lycaenidae) in Majorca. Entomologist's Record. 102, pp 250.

Sammut, P. 2007. Cacyreus marshalli Butler, (1898) reaches the Maltese Islands (Lepidoptera: Lycaenidae). SHILAP Revista de lepidopterología.35 (139), 317-319.

Sarto, I and V. Monteys. 1992. Spread of Southern African Lycaenid butterfly, Cacyreus marshalli Butler, 1898, (Lepidoptera: Lycaenidae) in the Balearic Archipelago (Spain) and considerations on its likely introduction to continental Europe. Journal of Research on the Lepidoptera. 31, 24-34.

Sibatanp, A., M. Ogata, Y. Okada and H. Okagaki. 1954. Male genitalia of Lepidoptera: Morphology and nomenclature I: Divisions of the valvae in rhopalocera, phalaenidae (Noctuidae) and geometridae. Ann. Entomol. Soc. Am. 47, 93-106.

Tarkan, S., S. Baser and V. Nazari. 2013. First record of Cacyreus marshalli Butler, 1898 (Lycaenidae) from Turkey. Nota lepid. 36 (2), 189-190.

Tshikolovets, V. V. 2011. Butterflies of Europe and the Mediterranean Area. Vadim Tshikolovets publications, 544 pp.

Tarrier, M. 1998. Cacyreus marshalli Butler,1898, a new species for France, Portugal and Morocco (Lepidoptera Lycaenidae). Alexanor. 20 (2-3),143-144.

Tolman, T and R. Lewington. 2009. Butterflies of Britain and Europe. Harper Collins Publishers, London. pp. 384. 
Trematerra, P., A. Zilli, V. Valentini and P. Mazzei. 1997. Cacyreus marshalli, un lepidottero sudafricano dannoso ai gerani First in Italia. Informatore Fitopatologico. 7-8, 2-6.
Verovnik, R., S. Polak and G. Seljak. 2011. Pojav in širenje tujerodne vrste dnevnega rtugal metulja - pelargonijevega bakrenčka (Cacyreus marshalli) (Butler, 1898) Sloveniji. Acta Entomologica Slovenica. 19 (1), 5-16.

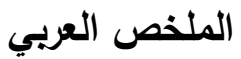

\section{وصف أبو دقيق البيلارجونيوم Cacyreus marshalli Butler}

\section{(Lepidoptera: Lycaenidae: Polyommatinae)}

$$
\text { محمد السيد توفيق، محمد على أبو غنيم، حنان محمد رمضان، أمانى مصطفى أبوشال }
$$

أغمق من الجهه البطنية. الذكر أقصر بقليل من الأنثى. والجناح الخلفي بني اللون مع وجود شرائط رفيعة بيضاء وبنية على الحواف في كلا الجنسين من الجهه الظهرية. تم وصف الصفات المميزة لهذا النوع من أبى دقيقات لكل من الجنسين الذكور والاناث. بالإضافة لذلك تم وصف وتصوير الشعرات الحسية المختلفة الموجودة على قرن الإستشعار بواسطة الميكروسكوب الإلكترونى.

الكلمات المفتاحية: فراشة البلارجونيوم، 1191)، دراسات

مورفولوجية، الشعيرات الحسية لقرن الاستشعار، الاعراض لراه

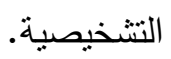

يعتبر أبو دقيق البيلارجونيم البرونزية، Cacyreus

:Lycaenidae :Lepidoptera) marshalli Butler, 1898 (Polyommatini :Polyommatinae

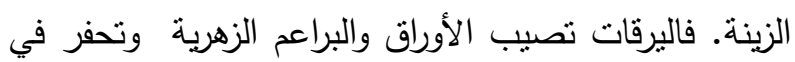
السيقان لنباتات Pelargonium zonale و P. inquinans من عائلة Geraniaceae فى العديد من مناطق محافظة الإسكندرية. وقد نم دراسة المورفولوجى لكل من البيضة، اليرقة، العذراء والحشرات الكاملة (ذكور وإناث) لأبى دقيق البيلارجونيم. وصفت البيضة بالتقصيل وقد تم تصويرها بالميكروسكوب الإكترونى. اليرقات مستطيلة الثكل مفلطحة

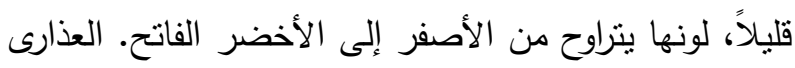
لها شعر طويل كثيف من الناحية الظهرية والجهة الظهرية 